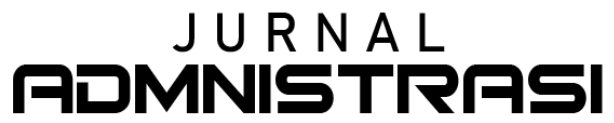 PLJE|K \\ PUSLATBANG KMP LAN RI
}

\section{VOLUME XVII NOMOR 2 DESEMBER 2021}

\section{Penanggung Jawab:}

Dr. Andi Taufik, M. Si

\section{Redaktur/Journal Editor:}

Anita, S. Sos., M. Si

\section{Mitra Bestari:}

Prof. Dr. Abdul Mahsyar, M. Si

Prof. Dr. Haedar Akib, M. Si

Prof. Dr. Irfan Ridwan Maksum, M. Si

Prof. Dr. Nurliah Nurdin., MA

Prof. Dr. Drs. Sam'un Jaja Raharja, M. Si

Prof. Dr. Sangkala., M. Si

Dr. Bevaola Kusumasari, M. Si

Dr. Rulinawaty, S. Sos., M. Si

Dr. St. Syamsudduha, M. Pd

Dr. Puji Lestari, M. Si

\section{Editor:}

Dr. Frida Chairunisa, M. Si

Dr. Halim, SH., MH

Dr. Johan Tarru Mada, M. Si

Dr. Phil. Sukri, PhD

Milawaty, SS., MM

Penyunting/Section Editor:

Ahmad Sukarno, S. IP., M. Adm. SDA

Syakib Arsalam, S. Hi., LL. M

Zaenal Z., S. Sos., M. Adm. Pemb.

Copy Editor \& Layout Editor:

Andi Dirga Putra, S. IP

Anisa Mifrohatun Fathiyah, S. I. A.

Avrina Dwijayanti, S. IP.

Ayun Sri Damayanti, SH., MH

Muskamal, S. Sos., M. Si

Nur Khasanah Latief, S. IP

Nur Masyita, S. Psi

Erman Fahruddin, S. Si

Desain Grafis:

Muhammad Iqbal, S. Sos., MA 


\section{JUMNISTLRASI \\ PUBLIK \\ PUSLATBANG KMP LAN RI}

Pusat Pelatihan dan Pengembangan dan Kajian Manajemen Pemerintahan

Lembaga Administrasi Negara (Puslatbang KMP LAN)

J1. Raya Baruga No. 48 Makassar, 90234

E-mail: jap@lan.go.id | URL: http://makassar.lan.go.id/jap

\section{CALL FOR PAPER:}

Redaksi menerima naskah hasil penelitian, analisis, kajian, pemikiran kritis, dan gagasan ilmiah dalam lingkup bidang administrasi publik yang belum diterbitkan di jurnal ilmiah lainnya. Naskah hendaknya diketik dalam MS Word menggunakan Bahasa Indonesia sepanjang 6000-8000 kata, ukuran A4, huruf Times New Roman ukuran 12 dan spasi 1,5. Abstrak ditulis dalam dwi bahasa (Bahasa Indonesia dan Bahasa Inggris) masing-masing sepanjang 100-200 kata. Naskah di-submit ke http: http://makassar.lan.go.id/jap atau dikirim melalui email ke Redaksi dalam bentuk soft file copy. Redaksi berhak melakukan penilaian dan penyuntingan terhadap naskah yang masuk. Naskah yang lolos seleksi akan di-review oleh Mitra Bestari (Reviewer).

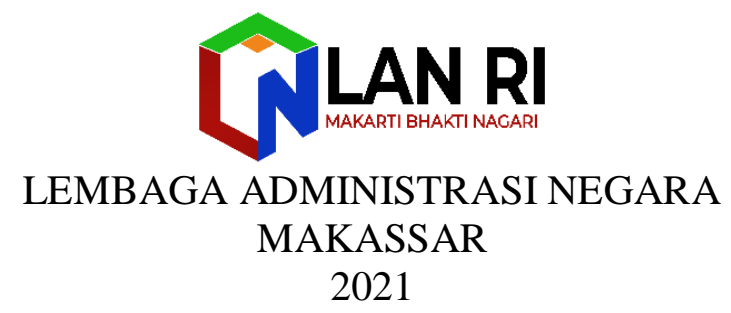


P-ISSN: 1858-2168

E-ISSN: 2621-251X

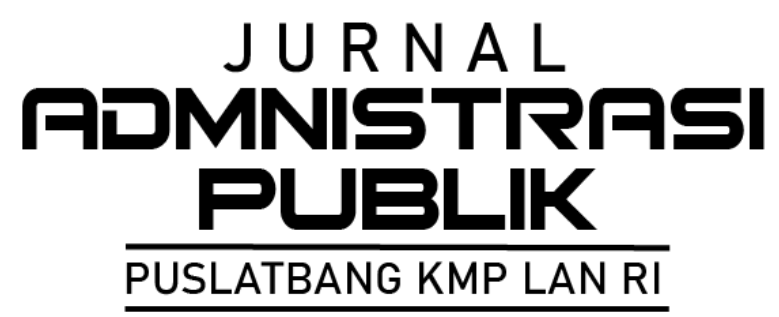

Volume XVII Nomor 2 Desember 2021

Hal. 175-304

1. ADAPTIF, AGILE, INOVATIF: KUNCI SDM UNGGUL 175-196 Grace V. Dumalang

2. TINGKAT KEPUASAN MASYARAKAT TERHADAP 197-210 PELAYANAN TERPADU SATU PINTU DI SULAWESI SELATAN

Yossi Findarta Pratama, Andi Fitriyani Yahya, Alsry Mulyani, Yuliana

Rauf, Rosmala Dewi Said, St. Suryani

3. FLYER PEMBELAJARAN DI ERA BARU : ANALISIS 211-231 PENYUSUNAN DAN PUBLIKASI

Jamila Lestyowati

4. PENERAPAN SOFT SKILL COACHING PADA 232-248 PENYUSUNAN AKTUALISASI (STUDI KASUS PADA PELATIHAN DASAR CPNS KABUPATEN PULAU MOROTAI)

Najemiah M. Amin

5. RESPONSIVITAS PENYELENGGARAAN PELAYANAN 249-266 PUBLIK DI DINAS KEPENDUDUKAN DAN PENCATATAN SIPIL KABUPATEN BONE

Rasdiana, Riski Ramadani

6. PEMULIHAN LANSKAP EKONOMI PASCA PANDEMI COVID- 267-282 19 DI KABUPATEN LABUHAN BATU

Andjar Prasetyo, Tomo Hadi Saputro, Amsal, Ray Septianis Kartika

7. INOVASI PELAYANAN PUBLIK DI KECAMATAN MALLAWA 283-304 KABUPATEN MAROS

Aprilia Hapsari, Muhammad Guntur, Novayanti Sopia Rukmana S 


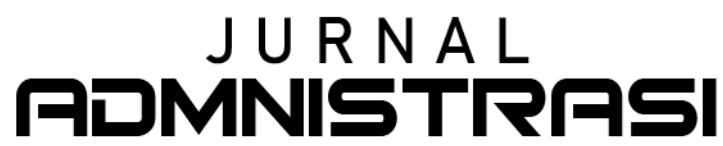 \\ PUBLIK \\ PUSLATBANG KMP LAN RI}

P-ISSN: 1858-2168

E-ISSN: 2621-251X

Volume XVII Nomor 2 Desember 2021

PENGANTAR REDAKSI

Pembaca yang berbahagia, puji syukur kami panjatkan ke hadirat Allah SWT karena Jurnal Administrasi Publik Volume XVII Nomor 2, Desember 2021 dapat kembali hadir ke hadapan pembaca.

Di edisi kali ini, Jurnal Administrasi Publik menghadirkan 7 artikel yang berfokus pada hasil penelitian di bidang Administrasi Publik maupun Pelatihan dan Pengembangan ASN. Tulisan pertama ditulis oleh Grace V. Dumalang dengan judul "Adaptif, Agile, Inovatif: Kunci SDM Unggul". Tulisan kedua berasal dari hasil penelitian yang dilakukan oleh Yossi Findarta Pratama, Andi Fitriyani Yahya, Alsry Mulyani, Yuliana Rauf, Rosmala Dewi Said, St. Suryani yang bertajuk " Tingkat Kepuasan Masyarakat Terhadap Pelayanan Publik di Sulawesi Selatan". Tulisan ketiga dihadirkan oleh Jamila Lestyowati dengan judul "Flyer Pembelajaran Di Era Baru: Analisis Penyusunan dan Publikasi". Tulisan keempat ditulis oleh Najemiah M. Amin yang diberi tajuk "Penerapan Soft Skill Coaching Pada Penyusunan Aktualisasi (Studi Kasus Pada Pelatihan Dasar CPNS Kabupaten Pulau Morotai)". Dalam tulisan kelima, Rasdiana, Riski Ramadani mencoba menuliskan hasil penelitiannya mengenai "Responsivitas Penyelenggaraan Pelayanan Publik di Dinas Kependudukan dan Pencatatan Sipil Kabupaten Bone". Tulisan keenam dihadirkan oleh Andjar Prasetyo, Tomo Hadi Saputro, Amsal, Ray Septianis Kartika yang mengambil judul "Pemulihan Lanskap Ekonomi Pasca Pandemi Covid-19 Di Kabupaten Labuhanbatu". Adapun tulisan ketujuh, ditulis oleh Aprilia Hapsari, Muhammad Guntur, Novayanti Sopia Rukmana S. dengan judul "Inovasi Pelayanan Publik di Kecamatan Mallawa Kabupaten Maros".

Redaksi Jurnal Administrasi Publik mengucapkan terima kasih dan memberikan apresiasi setinggi-tingginya kepada penulis yang telah bersedia mengirimkan naskahnya kepada kami. Tidak lupa kami mengundang pembaca untuk berpartisipasi mengirimkan tulisan yang dimiliki untuk Jurnal Administrasi Publik edisi selanjutnya.

Semoga setiap tulisan yang ada di dalam jurnal edisi ini dapat menjadi motivasi, sumbangan ide, serta tambahan ilmu bagi seluruh pembaca. Salam inovasi. 


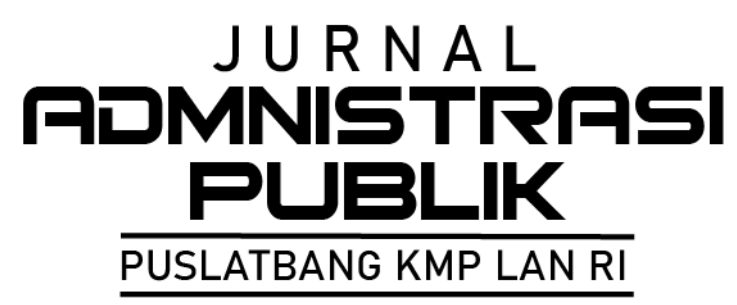

P-ISSN: 1858-2168

E-ISSN: 2621-251X

Volume XVII Nomor 2 Desember 2021

Lembar abstrak ini boleh diperbanyak/di-copy tanpa izin dan biaya

Grace V. Dumalang

Adaptif, Agile, Inovatif: Kunci SDM Unggul

Jurnal Administrasi Publik Volume XVII Nomor 2 Desember 2021, Hal. 175-196

Smart ASN merupakan suatu konsepsi dan nilai baru yang dicanangkan Pemerintah di Tahun 2019 di lingkungan birokrasi Indonesia guna mendorong para aparatur agar mampu beradaptasi menghadapi perubahan eksternal yang bersifat global di lingkungan birokrasi. Penelitian ini bertujuan untuk mendeskripsikan arah kebijakan yang dilakukan berbagai kabupaten/kota di Indonesia dalam upaya membangun SDM aparatur yang berkualitas dalam rangka mewujudkan Smart ASN. Metode penelitian yang penulis gunakan adalah metode PRISMA (Preferred Reporting Items for Systematic Reviews and Meta-analyses) dengan pertimbangan protokol riset metode PRISMA detail dan lengkap yang memungkinkan terhindar dari bias subjektif pada saat melakukan kajian literature. Hasil penelitian menunjukkan bahwa arah kebijakan yang dilakukan pemerintah kab/kota di Indonesia dalam upaya membangun SDM aparatur yang berkualitas dalam rangka mewujudkan Smart ASN pada dasarnya telah mengarah pada Grand Design Pembangunan ASN 2020-2024 yang terdiri dari perencanaan, perekrutan dan seleksi, pengembangan kompetensi, penilaian kinerja dan penghargaan, promosi, rotasi dan karir, serta peningkatan kesejahteraan. Keenam pemerintah daerah dalam penelitian ini telah bergerak ke arah strategi di atas meski masih banyak hal yang perlu disesuaikan dan disempurnakan dalam penerapannya.

Kata Kunci: Smart ASN; SDM Aparatur; Agile; Grand Design Pembangunan ASN 2020-2024

Yossi Findarta Pratama, Andi Fitriyani Yahya, Alsry Mulyani, Yuliana Rauf, Rosmala

Dewi Said, St. Suryani

Tingkat Kepuasan Masyarakat Terhadap Pelayanan Publik di Sulawesi Selatan

Jurnal Administrasi Publik Volume XVII Nomor 2 Desember 2021, Hal. 197-210

Penelitian ini dilakukan untuk mengetahui nilai indeks kepuasan masyarakat (IKM) untuk Pelayanan Terpadu Satu Pintu (PTSP) di Sulawesi Selatan. Metode penelitian 
menggunakan pendekatan kuantitatif melalui survei pada unit pelayanan publik PTSP di Kota Makassar, Kabupaten Barru dan Kabupaten Bantaeng. Responden penelitian adalah penerima layanan di unit layanan tersebut. Jumlah responden yang dilibatkan adalah 527 orang. Hasil penelitian menunjukkan bahwa Indeks Kepuasan Masyarakat (IKM) unit pelayanan publik di Sulawesi Selatan memiliki nilai IKM sebesar 81,29 yang ekuivalen dengan nilai B dan berkinerja baik sesuai dengan kategori mutu pelayanan berdasarkan Permenpan Nomor 14 Tahun 2017.

Kata kunci: Indeks Kepuasan Masyarakat, IKM, Pelayanan Terpadu Satu Pintu

Jamila Lestyowati

\section{Flyer Pembelajaran Di Era Baru: Analisis Penyusunan dan Publikasi}

Jurnal Administrasi Publik Volume XVII Nomor 2 Desember 2021, Hal. 211-231

Pembelajaran daring BPPK pada awal dan selama masa pandemi Covid-19 diselenggarakan melalui kegiatan Pelatihan Jarak Jauh, E-Learning, Kemenkeu Corpu Open Class, Kemenkeu Corpu Talk dan seminar online sebagai andalannya. Dengan beragam kelebihan yang dimilikinya, kegiatan tersebut menjadi daya tarik bagi stakeholder baik langsung maupun tidak langsung untuk mengikutinya karena beragam tema yang ditawarkan melalui publikasi yang menarik. BPPK menggunakan media flyer untuk menyebarluaskan informasi pembelajaran online. Melalui flyer, informasi kegiatan menjadi menyebar luas. Penelitian ini bertujuan untuk menganalisis penyusunan flyer dan publikasinya pada layanan publik pembelajaran daring di masa pandemi Covid-19. Penelitian menggunakan metode kualitatif deskriptif dengan pendekatan eksplanatoris menggunakan sumber data sekunder berupa flyer dari media sosial. Hasil penelitian menunjukkan bahwa terdapat flyer yang tidak memenuhi standar pembuatannya. Hal ini karena adanya unsur kreatifitas dari pembuat flyer. Publikasi flyer dilakukan melalui media sosial resmi yang dimiliki unit penyelenggara dan disebarluaskan oleh unit kerja lain pada BPPK. Media sosial yang sering digunakan adalah Instagram, facebook, whatsapp dan email. Walaupun memiliki beberapa kelemahan, namun publikasi kegiatan melalui flyer ini mampu diandalkan.

Kata kunci: Kemenkeu Corpu Open Class; Kemenkeu Corpu Talks; Layanan Publik; Pembelajaran Daring; Publikasi Poster/ Flyer.

Najemiah M. Amin

\section{Penerapan Soft Skill Coaching Pada Penyusunan Aktualisasi (Studi Kasus Pada Pelatihan Dasar CPNS Kabupaten Pulau Morotai)}

Jurnal Administrasi Publik Volume XVII Nomor 2 Desember 2021, Hal. 233-247

Latar belakang penelitian adalah peserta pelatihan dasar mengalami kesulitan dalam memunculkan ide atau gagasan serta kegiatan-kegiatan yang akan dilakukan, padahal seharusnya peserta tidak harus mengalami kesulitan dalam penentuan gagasan aktualisasi karena berkaitan dengan tugas dan fungsi peserta. Maka penelitian bertujuan menemukan pertama, mengetahui prinsip coaching penulisan aktualisasi dan kedua mengetahui penerapan soft skill coaching dalam penulisan aktualisasi. Metode penelitian yang digunakan dalam penelitian ini adalah metode kuantitatif. Sampel yang digunakan dalam penelitian adalah alumni Pelatihan Dasar Calon Pegawai Negeri Sipil Golongan III 
Kabupaten Pulau Morotai sebanyak 40 orang. Teknik pengumpulan data yang digunakan dalam penelitian adalah studi kepustakaan, penyebaran kuisioner dan wawancara. Teknik analisis data dilakukan dengan metode deskriptif kualitatif. Hasil penelitian diketahui bahwa, pertama prinsip coaching penulisan aktualisasi sudah berjalan dengan baik namun diperlukan penguatan pada aspek coach lebih banyak mendengar serta berkomitmen menyusun strategi kedepannya. Kedua, penerapan soft skill coaching dalam penulisan aktualisasi sudah berjalan dengn baik tetapi masih perlu penguatan pada aspek perilaku sopan santun. Maka secara keseluruhan diperlukan peningkatan kompetensi coaching secara berkesinambungan.

Kata Kunci: Soft skill, Coaching, Aktualisasi

Rasdiana, Riski Ramadani

\section{Responsivitas Penyelenggaraan Pelayanan Publik di Dinas Kependudukan dan Pencatatan Sipil Kabupaten Bone}

Jurnal Administrasi Publik Volume XVII Nomor 2 Desember 2021, Hal. 249-265

Responsivitas sebagai salah satu indikator dalam pelayanan publik yang berkaitan dengan daya tanggap aparatur negara terhadap kebutuhan masyarakat yang membutuhkan pelayanan sebagaimana yang diatur dalam perundang-undangan. Penelitian ini bertujuan untuk menjelaskan responsivitas penyelenggaraan pelayanan publik pada Dinas Kependudukan dan Pencatatan Sipil Kabupaten Bone. Penelitian ini menggunakan pendekatan kualitatif dengan jenis deskriptif. Adapun sumber penelitian terdiri dari data primer yaitu wawancara mendalam dengan informan, informan berasal dari aparat pemerintah di Dinas Kependudukan dan Pencatatan Sipil Kabupaten Bone serta masyarakat sedangkan data sekunder berasal dari dokumentasi. Data penelitian dikumpul dengan observasi partisipasi. wawancara mendalam dan dokumentasi. Data tersebut dianalisis dengan teknik reduksi data, penyajian data dan studi dokumentasi. Kemudian dilakukan pengabsahan data dengan triangulasi sumber, tiangulasi teknik dan triangulasi waktu. Hasil penelitian ini menunjukkan kemampuan merespon masyarakat sudah baik terlihat dari penggunaan nomor handpone Kepala Dinas sebagai nomor publik, kecepatan melayani kurang baik diakibatkan oleh jaringan yang biasa eror dan aparatur pemerintah kurang dibandingkan dengan masyarakat yang banyak, ketepatan melayani sudah baik sesuai dengan standar operasional prosedur, kecermatan melayani sudah baik karena telah berbasis elektronik, ketepatan waktu pelayanan yaitu waktu proses sampai verifikasi harus sesuai jadwal, kemampuan menaggapi keluhan sudah baik karena telah menerima pengaduan dan pengisian Google Form yang diterapkan Dinas Kependudukan dan Pencatatan Sipil Kabupaten Bone.

Kata kunci: Responsivitas; Penyelenggaraan; Pelayanan Publik

Andjar Prasetyo, Tomo Hadi Saputro, Amsal, Ray Septianis Kartika Pemulihan Lanskap Ekonomi Pasca Pandemi Covid-19 Di Kabupaten Labuhanbatu

Jurnal Administrasi Publik Volume XVII Nomor 2 Desember 2021, Hal. 267-282

Tujuan dari kajian adalah mendeskripsikan dan menganalisa dampak pandemi Covid-19 terhadap kondisi ekonomi masyarakat Labuhanbatu. Metode kajian menggunakan 
kualitatif yang dideskripsikan dengan rasional, empiris, dan sistematis dalam menerangkan fenomena ekonomi. Sumber data sekunder dari Badan Pusat Statistik Labuhanbatu, data primer dari kuisioner. Populasi adalah penduduk berusia 15 tahun ke atas yang bekerja berdasarkan lapangan usaha di Kabupatan Labuhanbatu tahun 2020. Penentuan sampel didasarkan dengan Two Stage Cluster, sampel primer sebanyak 156.223 orang, asumsi sampling error sebesar 0,22\%, asumsi koefisien kepercayaan sebesar 1,96 dan asumsi parameter proporsi binomial sebesar 50\%-50\% diperoleh sampel sebanyak 797 orang. Waktu penelitian mulai Maret - November 2020 dengan lokasi di 9 (sembilan) kecamatan se Kabupaten Labuhanbatu. Pengumpulan data dengan survey terhadap instrumen berupa kuisioner terbuka yang dibagi menjadi dua bagian, kuisioner terbuka administratif dan kuisioner terbuka substantif. Temuan administratif masyarakat yang bekerja di lokus studi didominasi laki-laki dengan umur antara 30-49 tahun dan berpendidikan SMA. Temuan substantif dalam studi ini adalah adanya perubahan kondisi ekonomi di Kabupaten Labuhanbatu yang ditandai dengan pekerjaan yang berkurang, distribusi bantuan pemerintah yang meningkat, kelangkaan kebutuhan pokok, penghasilan semakin menurun dan perubahan peta lapangan usaha. Upaya yang dilakukan diharapkan pada sektor-sektor informal agar produktivitas mereka dapat ditingkatkan, dibutuhkan peningkatan kapasitas dan kemampuan baik pada lapangan usaha maupun sektor informal, pengembangan infrastruktur yang mendukung pemanfaatan teknologi dan penguatan digital marketing dengan pendekatan platform online yang bersedia bersinergi dan perlindungan ketenagakerjaan dengan skema yang seimbang. Pandemi Covid-19 memiliki dampak terhadap dinamika pekerjaan, distribusi bantuan pemerintah, kelangkaan kebutuhan pokok, penghasilan dan pergeseran lapangan usaha.

Kata kunci: Covid-19, kondisi ekonomi, pemulihan Labuhanbatu

\section{Aprilia Hapsari, Muhammad Guntur, Novayanti Sopia Rukmana S. Inovasi Pelayanan Publik di Kecamatan Mallawa Kabupaten Maros}

\section{Jurnal Administrasi Publik Volume XVII Nomor 2 Desember 2021, Hal. 283-304}

Penelitian ini bertujuan untuk menguraikan secara mendalam mengenai proses pelayanan publik dalam laporan pertanggungjawaban dana desa yang saat ini diterapkan dan melakukan penawaran konsep aplikasi yang berfokus pada laporan pertanggungjawaban dana desa di Desa Tellumpanaue dan Desa Barugae Kecamatan Mallawa Kabupaten Maros. Oleh karena itu, penulis memberikan solusi terhadap masalah yang ada dengan sistem pelayanan sebelumnya yaitu dengan aplikasi PAKDES. Aplikasi ini dirancang sebagai salah satu media yang dapat memudahkan aparatur desa dalam melakukan pelaporan dana desa yang dapat diakses melalui smartphone. Penelitian ini menggunakan metode penelitian kualitatif deskriptif yang akan menjabarkan secara lebih dalam fokus masalah yang akan diteliti. Adapun sumber data diperoleh melalui dokumen-dokumen pendukung serta beberapa aparatur desa yang terlibat yaitu Kepala Desa, Kaur Keuangan dan Operator Desa. Teknik analisis data menggunakan model Miles dan Huberman, melalui reduksi data, penyajian data, serta penarikan kesimpulan. Pada peroses penelitian, peneliti menemukan data bahwa proses pertanggungjawaban yang saat ini diterapkan di Desa Barugae dan Desa Tellumpanuae Kecamatan Mallawa Kabupaten Maros telah mengalami pergeseran sistem, dari yang sebelumnya masih menggunakan sistem manual, saat ini telah beralih ke Sistem Keuangan Desa (Siskeudes). Meskipun belum melakukan uji coba, namun secara keseluruhan, aparatur desa memiliki ketertarikan dengan desain prototype aplikasi yang peneliti tawarkan, yaitu aplikasi Pakdes karena memiliki tampilan 
fitur dan fungsi yang lebih fleksibel dan dapat dijangkau oleh masyarakat secara umum. Hal ini sangat mendukung beberapa prinsip pelayanan yang seharusnya ada dan diterapkan, salah satunya prinsip partisipatif yang diharapkan agar segera dilakukan uji coba aplikasi.

Kata Kunci: Inovasi Pelayanan Publik; Dana Desa; Aplikasi Pakdes. 


\section{JUUN R AL \\ PUBLIK \\ PUSLATBANG KMP LAN RI}

P-ISSN: 1858-2168

E-ISSN: 2621-251X
Volume XVII Nomor 2 Desember 2021

The abstract sheet may be reproduced/copied without permission or charge.

Grace V. Dumalang
Adaptive, Agile, Innovative : The Key to Excellent Human Resources
Jurnal Administrasi Publik Volume XVII Number 2 December 2021, Page 175-196
Smart ASN is a new concept and value launched by the Government in 2019 in Indonesian
bureaucracy to encourage the apparatus to be able to adapt to global external changes
in the bureaucratic environment. This study aims to describe the direction of policies
carried out by various districts/cities in Indonesia in an effort to develop quality human
resources for the apparatus in order to realize Smart ASN. The research method uses
PRISMA (Preferred Reporting Items for Systematic Reviews and Meta-analyses) method
with consideration of a detailed and complete PRISMA research protocol that allows
avoiding subjective bias when conducting a literature review. The results of the study
indicate that the direction of policies carried out by district/city governments in Indonesia
in an effort to develop quality human resources in the context of realizing Smart ASN has
basically led to Grand Design of ASN Development 2020-2024 which consists of planning,
recruitment and selection, competency development, performance appraisals and
rewards, promotions, rotations and careers, and welfare enhancement. The six local
governments in this study have moved towards the above strategy, although there are still
many things that need to be adjusted and perfected in their implementation.
Keywords: Smart ASN; SDM Aparatur; Agile; Grand Design Pembangunan ASN $2020-$
2024
The research is accomplished to know a value of the community satisfaction index for the
one-gate integrated service in South Sulawesi. The research approach employs the
quantitative approach with the survei method at the public service of the one-gate
integrated service in Makassar city, Barru regency, and Bantaeng regency. The
respondents are the service recipient of the subdivision. The number of the respondents
involved are 527 people. As a result of the research, the community satisfaction index of
the subdivision in South Sulawesi has the IKM value of 81.29, equivalent to the value of


$B$ and good performance with refer to the category of the service quality on the basis of Permenpan Nomor 14 Tahun 2017.

Keywords: coaching, mentoring, counselling, coach's competencies and qualifications, coaching model and techniques

\section{Jamila Lestyowati \\ Learning Flyer in the New Era: Analysis of creation and publication}

Jurnal Administrasi Publik Volume XVII Number 2 December 2021, Page 211-231

BPPK's online learning at the beginning and during the Covid-19 pandemic was through Distance Training, E-Learning, Ministry of Finance Corpu Open Class, Ministry of Finance Corpu Talk, and online seminars as its mainstay. With its various advantages, the activity attracts stakeholders, both directly and indirectly, to participate because of the multiple themes offered through exciting publications. BPPK uses flyer media to disseminate online learning information. Through flyers, information on activities is widely spread. This study aims to analyze the preparation of flyers and their publications on online learning public services during the COVID-19 pandemic. The study used a descriptive qualitative method with an explanatory approach using secondary data sources in posters/flyers from social media. The results showed that there were flyers that did not meet the manufacturing standards. The condition is due to the creative element of the flyer maker. Publication of flyers is carried out through social media owned by the organizing unit and disseminated by other work units at the BPPK. The social media that are often used are Instagram, Facebook, WhatsApp, and email. Although it has several weaknesses, the publication of activities through this flyer is reliable.

Keywords: Ministry of Finance Corpu Open Class; Ministry of Finance Corpu Talks; Public Service; Online Learning; Publication of Posters/ Flyers

\section{Najemiah M. Amin \\ Implementation of Coaching Soft Skill in the Making of Actualization Project (Case Study on the Basic Training for Civil Servant Candidate of Morotai Island Regency)}

Jurnal Administrasi Publik Volume XVII Number 2 December 2021, Page 233-247

The background of the research is that basic training participants have difficulty in generating ideas or ideas as well as the activities to be carried out, even though participants should not have to experience difficulties in determining the idea of actualization because it is related to the tasks and functions of the participants. This research aims to find first, to know the principles of coaching writing actualization and secondly to find out the application of soft skills coaching in writing actualization. The research method used in this study is a quantitative method. The sample used in this study was 40 people of Basic Training Alumni of Candidates for Civil Servants Group III Morotai Island Regency. Data collection techniques used in this research are literature study, questionnaire distribution and interviews. The data analysis technique was carried out using a qualitative descriptive method. The results of the study show that, firstly, the principle of coaching writing actualization has been going well, but it is necessary to strengthen the aspect of the coach listening more and being committed to formulating future strategies. Second, the application of soft skills coaching in writing actualization 
has been going well but still needs to be strengthened in the aspect of polite behavior. So overall it is necessary to improve coaching competence on an ongoing basis.

Keywords: Soft skills, Coaching, Actualization

\section{Rasdiana, Riski Ramadani \\ Responsiveness of Public Service Delivery at the Population and Civil Registration Office of Bone Regency}

Jurnal Administrasi Publik Volume XVII Number 2 December 2021, Page 249-265

Responsiveness as an indicator in public services related to the responsiveness of the state apparatus to the needs of the people who need services as regulated in the legislation. Therefore. This study aims to explain the responsiveness of public service delivery at the Department of Population and Civil Registration of Bone Regency. This study uses a qualitative method with a descriptive type while the research sources consist of primary data and secondary data, the determination of informants also comes from government officials at the Population and Civil Registration Office of Bone Regency and the community. Research data were collected by Participation Observation. In-depth interviews and documentation studies. The data were analyzed by data reduction techniques, data presentation and documentation studies. Then validated the data by source triangulation, technique mastulation and time triangulation. The results of this study indicate that the ability to respond to the community is good, as can be seen from the use of the Head of Service's mobile number as a public number, the speed of service is not good due to the usual network errors and less government apparatus compared to many people, the accuracy of serving is good in accordance with standard operating procedures, Accuracy in serving is good because it is electronically based, timeliness of service, namely processing time until verification must be on schedule, ability to respond to complaints is good because it has received complaints and filled out Google Forms implemented by the Population and Civil Registration Office of Bone Regency.

Keywords: Responsiveness; Maintenance; Public service

\section{Andjar Prasetyo, Tomo Hadi Saputro, Amsal, Ray Septianis Kartika Post-Covid-19 Pandemic Economic Recovery In Labuhanbatu District}

Jurnal Administrasi Publik Volume XVII Number 2 December 2021, Page 267-282

The purpose of this study is to describe and analyze the impact of the Covid-19 pandemic on the economic conditions of the Labuhanbatu community. The study method uses qualitative descriptions that are rational, empirical, and systematic in explaining economic phenomena. Secondary data sources from the Central Statistics Agency Labuhanbatu, primary data from questionnaires. The population is residents aged 15 years and over who work based on business fields in Labuhanbatu Regency in 2020. The determination of the sample is based on Two Stage Clusters, the primary sample is 156,223 people, the sampling error assumption is $0.22 \%$, the Confidence Coefficient assumption is 1.96 and assuming the binomial proportion parameter of 50\%-50\%, a sample of 797 people was obtained. The research time is from March to November 2020 with locations in 9 (nine) sub-districts in Labuhanbatu Regency. Collecting data by surveying the instrument in the form of an open questionnaire which is divided into two parts, an administrative open questionnaire, and an open substantive questionnaire. The 
administrative findings of the people working at the study locus were dominated by men aged between 30-49 years and had a high school education. The substantive findings in this study are changes in economic conditions in Labuhanbatu Regency which are characterized by reduced employment, increased distribution of government assistance, scarcity of basic needs, declining income and changes in the business field map. The efforts made are expected to be in the informal sector so that their productivity can be increased, capacity and capacity building is needed both in the business field and the informal sector, infrastructure development that supports the use of technology and strengthening digital marketing with an online platform approach that is willing to synergize and protect employment with schemes. The Covid-19 pandemic has an impact on the dynamics of work, distribution of government assistance, scarcity of basic needs, income and shifts in business fields.

Keywords: Covid-19, Economic landscape, Recovery

\section{Aprilia Hapsari, Muhammad Guntur, Novayanti Sopia Rukmana S Public Service Innovation in Kecamatan Mallawa Maros Regency}

\section{Jurnal Administrasi Publik Volume XVII Number 2 December 2021, Page 283-304}

This study aims to describe in depth the public service process in village fund accountability reports that are currently being implemented and offer an application concept that focuses on village fund accountability reports in Tellumpanaue Village and Barugae Village, Mallawa District, Maros Regency. Therefore, the authors provide solutions to existing problems with the previous service system, namely the PAKDES application. This application is designed as a medium that can facilitate village apparatuses in reporting village funds that can be accessed via smartphones. This study uses a descriptive qualitative research method which will describe more deeply the focus of the problem to be studied. The data sources were obtained through supporting documents and several Village Apparatuses, in this case those involved were the Village Head, Head of Finance and Village Operators. The data analysis technique uses the Miles and Huberman model, through data reduction, data presentation, and drawing conclusions. In the research process, researchers found data that the accountability process currently implemented in Barugae Village and Tellumpanuae Village, Mallawa District, Maros Regency has experienced a system shift, from previously still using a manual system, now has switched to the Village Financial System (Siskeudes). Although they have not yet conducted a trial, overall, village officials are interested in the prototype application design that researchers offer, namely the Pakdes application because it has a more flexible display of features and functions and can be reached by the general public. This strongly supports several service principles that should exist and be applied, one of which is the participatory principle which is expected to be tested immediately.

Keywords: Public Service Innovation; Village Funds; Pakdes Application. 